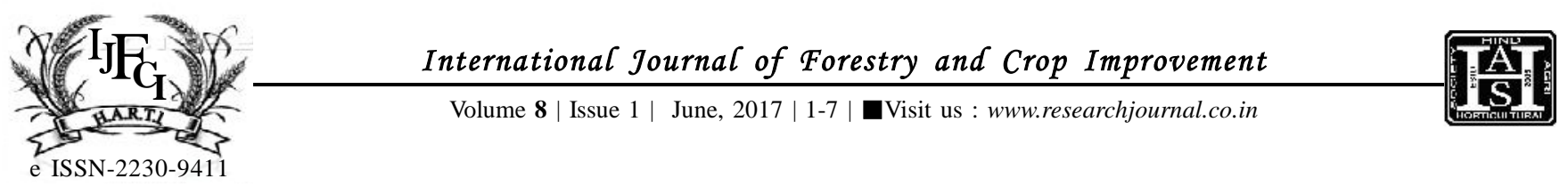

\title{
Relative performance of grass, cowpea varieties and row ratios on growth, productivity and economics of fodder crops
}

\author{
M.R. ANITA ANDS. LAKSHMI
}

\begin{abstract}
Field experiment was conducted at the Instructional Farm, College of Agriculture, Vellayani, Thiruvananthapuram during January 2012 to March 2014 to find out the effect of grass-fodder cowpea mixtures and row ratio on the growth characters, yield and economics of fodder grasses and fodder cowpea in open and in partial shade. The investigation was conducted as two separate experiments, one in open and another in shaded situation (25-35\% shade). The experiment was laid out in RBD with three replications, comprising of two grasses $\left[\mathrm{G}_{1}\right.$-Hybrid napier (Suguna), $\mathrm{G}_{2}$-Guinea grass (Harithasree)], two fodder cowpea varieties ( $\mathrm{V}_{1}$-COFC-8 (open and shade), $\mathrm{V}_{2}-\mathrm{UPC}-622$ (open), UPC-618 (shade) and three grass legume row ratios $\left(\mathrm{R}_{1}-1: 1, \mathrm{R}_{2}-1: 2, \mathrm{R}_{3}-1: 3\right)$. The results indicated the superiority of the grass legume mixture of hybrid napier cv. SUGUNA and with both the fodder cowpea varieties in the grass legume row ratio of 1:2 with respect to growth characters, green fodder yield and net returns. Based on the results, it can be concluded that hybrid napier cv. SUGUNA intercropped with fodder cowpea varieties COFC-8 and UPC-622 in open condition and with COFC-8 and UPC-618 in partial shade (30\%) in the row ratio of 1:2 is the best for obtaining maximum yield, quality and net returns.
\end{abstract}

KEY WORDS : Grass, Cowpea varieties, Row ratios, Growth, Productivity, Fodder crops

How TO CITE THIS ARTICLE : Anita, M.R. and Lakshmi, S. (2017). Relative performance of grass, cowpea varieties and row ratios on growth, productivity and economics of fodder crops. Internat. J. Forestry \& Crop Improv., 8 (1) : 1-7, DOI: 10.15740/HAS/IJFCI/8.1/1-7.

Article Chronical : Received : 15.12.2016; Revised : 25.04.2017; Accepted : 05.05.2017

MEMBERS OF RESEARCH FORUM

Address of the Coopted Authors : S. LAKSHMI, College of Agriculture, VELLAYANI (KERALA) INDIA 